\title{
Film Narrator and the Early American Screenwriting Manuals
}

Some of the most influential accounts of the transition from the cinema of attractions to narrative cinema have relied heavily on the figure of the film narrator. Tom Gunning (1994), for instance, has explained D.W. Griffith's innovations in terms of Genettian extradiegetic narrator. André Gaudreault (2009) has argued that the filmic narrative agency existed even before these developments in editing in the figure of the monstrator. This paper argues that in general early narrative cinema introduced no such narrators. The argument is twofold. First, I demonstrate that film narrators Gunning and Gaudreault speak of are not merely theoretical abstractions but entities which populate fictional worlds much like fictional characters do. Yet the ontological aspects of their theories hinge on a formally invalid argument that can be tracked to Christian Metz and Albert Laffay. Although this means that fictional narratives do not necessarily introduce fictional narrators, it does not mean that they cannot. If narrative cinema introduced fictional narrators, then the best-case scenario in support of Gunning and Gaudreault's view is that these were so novel that they were identified by their contemporaries. In the second part of the paper, therefore, I turn to historical data. I show that even the arguably most informed contemporary writings on the subject - screenwriting manuals - fail to identify any such entities. In fact, in making their own vocal ontological claims about the absence of film narrators the manuals present an alternative theory to Gunning and Gaudreault's which articulates how a fictional narrative can proceed without a fictional narrator.

Keywords: film narrator; monstrator; screenwriting manuals; transitional era; D.W. Griffith

The Version of Record of this manuscript has been published and is available in Early Popular Visual Culture 09 Jun 2019

https://www.tandfonline.com/doi/full/10.1080/17460654.2019.1623058

\section{Is there a film narrator?}

If the existence of a narrative in film is a necessary criterion for the existence of a film narrator can we say that the latter appears immediately with the appearance of the 
former? In other words, do all film narratives have a film narrator by definition? With some notable exceptions, this is indeed the prevalent view among film scholars, so prevalent that the debates about the existence of film narrators take place only on the fringes of the discipline. ${ }^{i}$ As such, this paper hopes to reanimate the interest in the question whose answer has been taken for granted for quite some time, by arguing not only that the accepted answer is mistaken but that by reopening the question we gain theoretical and historical insights alike. This is best fleshed out by engaging perhaps the key two book-length accounts of narration in early cinema - Tom Gunning's $D$. $W$. Griffith and the Origins of American Narrative Film and André Gaudreault's From Plato to Lumière -which claim that fictional narrators emerge in the early period and remain the mainstay of cinema to this very day. ${ }^{\text {ii }}$ This is how Gunning and Gaudreault articulate their position:

Because film's narrative discourse represents the actual text of a film - its existence as a series of filmic images - no narrative film can exist except through its narrative discourse. It logically follows that every narrative film has a filmic narrator embodied by this discourse. (Gunning 1994, 21) A narrative work (a film, a novel, or another work) would thus be the result of a tension between two poles: on the one hand, the diegetic universe (the story told), and on the other, the agent that organizes this world (the storyteller). [...] Every narrative is simultaneously a discourse (the discourse of the storyteller) and a story (the story told). (Gaudreault 2009, 58)

I argue that this generally accepted view is mistaken for two reasons. First, because there exist narratives without narrators and because it is possible to narrate fictionally without fictionally narrating. Second, because contemporary accounts of early cinema in the trade press which are best placed to spot potentially novel ontological entities such as film narrators strongly suggest that one of the main differences between literary and film fiction is precisely the absence of narrators in the latter. The goal of the article, 
therefore, is to move away from linguistic models which have informed our understanding of narration for far too long and to appreciate the discourse in screenwriting manuals as serious contributions to the discussions about the ontology of film narrators.

When it comes to fictional narratives to which both devote most of their attention, it is crucial to understand that Gunning and Gaudreault alike emphasize that the narrator is not the flesh and blood author but an entity internal to the text. In other words, in fiction film the narrator is fictional and as such distinct from the actual author. In this Gunning and Gaudreault are fully in line with Gerard Genette's key articulation of the distinction between the narrator and the author:

It is not Abbé Prévost who tells of the love of Manon and Des Grieux, it is not even the Marquis de Renoncourt, supposed author of the Mémoires d'un homme de qualité; it is Des Grieux himself, in an oral narrative where 'I' can designate only him, and where 'here' and 'now' refer to the spatiotemporal circumstances of that narrating and in no way to the circumstances of the writing of Manon Lescaut by its real author. And even the references in Tristram Shandy to the situation of writing speak to the (fictive) act of Tristram and not the (real) one of Sterne; in a more subtle and also more radical way, the narrator of Pere Goriot 'is' not Balzac, even if here and there he expresses Balzac's opinions, for this author-narrator is some-one who 'knows' the Vauquer boardinghouse, its landlady and its lodgers, whereas all Balzac himself does is imagine them; and in this sense, of course, the narrative situation is never reduced to its situation of writing. (Genette 1980, 214, italics in the original)

Most importantly, Gunning and Gaudreault's invocation of the film narrator does not only purport to explain in pragmatic terms how film narratives are understood. Film narrator is not merely a theoretical abstraction for these scholars. Gunning and Gaudreault's claims about the existence of film narrators are also ontological. For Gunning, for instance, this is clear from the fact that the Genettian narrator he 
subscribes to is a fictional entity which is a part of the work's fictional world. In the above example, the anonymous narrator of Pere Goriot is fictional in the same sense that character-narrators Des Grieux and Tristram Shandy are fictional. ${ }^{\mathrm{iii}}$ And their acts of narrating are fictional in the sense that the acts of fictional characters, such as Eugène de Rastignac moving to Paris, are fictional. As Gunning puts it: 'The story is an imaginary construction that the spectator or reader creates while reading the narrative discourse of the actual text. Likewise, access to the act of narrating (in written literature and in film, at least) is dependent on the traces of telling that exist in the text.' (Gunning 1994, 15). Given that fiction is that what the spectator or reader are mandated or supposed to imagine based on the text, both the narrator and the act of narrating are fictional for Gunning. Mandate, here, should be understood as a normative category meaning that it only describe what readers and spectators should do. Of course, they can refuse the mandate, imagine something completely different, or make a mistake like the anecdotal rube stopping the theatre performance to save Desdemona. But to properly play the game of make-believe that is fiction they should observe the mandates. ${ }^{\text {iv }}$

For Gaudreault it is no different. He explicitly quotes Albert Laffay's early narratological piece to describe the film narrator as a sort of a fictional character: '[Laffay] define[d] with great theoretical precision and adroitness the figure that stands in the background of all film narrative works, although he did not yet dare call that figure the "film narrator." For Laffay, this figure is a "fictive and invisible character [...]"' (Gaudreault 2009, 5).

The logic behind both Gunning's and Gaudreault's arguments, then, is essentially that of Laffay as popularized by Christian Metz (1974, 20-21): because narrative discourse, i.e. the presentation of a story is nothing but the narrative text itself, there necessarily needs to be an agent doing this presenting, i.e. the narrator. In other 
words, because every narrative work is a product of narrating there needs to be a narrator. There is certainly nothing problematic in claiming with Gaudreault and Gunning that if there is narrating then there needs to be a narrator. In fact, this is a tautology. The problem arises because at the same time they mean that if there is narrating of a fictional story then there needs to be a fictional narrator. But this is as formally valid as saying that if there is narrating of a short story then there needs to be a short narrator. It is true that, as Gunning points out, if there is a message, construed as an intentional artefact, then there is also a sender. But if the message has a content which mandates specific imaginings it does not follow that these mandates also include imagining a sender, i.e. a fictional narrator. The same is especially true of visual messages.

This, however, does not necessarily preclude the possibility that the specific narrative films that Gaudreault and Gunning focus on mandate imagining narrators. Gaudreault, for instance, distinguishes between two agents of narrative discourse in film - the monstrator and the narrator proper. Whereas the latter appears only with editing and oversees connecting the shots into a sequence the former is ushered into existence with the earliest film narratives and controls the showing of the content of single-shot films. In other words, for Gaudreault a specific form of the narrator - the monstrator should already be present in films like The Arrival of a Train/L'arrivée d'un train en gare de La Ciotat (Auguste and Louis Lumière, 1895, 1896, 1897) or The Haverstraw Tunnel (American Mutoscope and Biograph Company, 1897).

Gaudreault cites contemporary sources - judicial decisions - as proof of his claims. Specifically, two copyright lawsuits and their accompanying decisions from 1902 and 1905, according to Gaudreault, present the first identifications and articulations of the concepts of monstrator and narrator proper, respectively. The first 
lawsuit concerns an actuality film so the conclusions he draws from it cannot be applied to the discussion of fictional narrators. But his discussion of the 1904 Personal originally shot by American Mutoscope and Biograph Company and quickly duped by the Edison Manufacturing Company under the title How a French Nobleman Got a Wife through the 'New York Herald' Personal Columns clearly can.

The 1902 lawsuit determined that it is sufficient to copyright only one photograph from a single-shot film to copyright the whole film and thus articulated film not as a mere amalgam of photographs but as a unity of these photographs. For Gaudreault this means that it has been recognized that the photographs are linked together through a discourse whose agent is none other than the narrator proper. Once Porter duped the American Mutoscope and Biograph Company's Personal in 1904, Biograph quickly sued the Edison Manufacturing Company arguing that given that Biograph had copyrighted one photograph from their film the whole film is copyrighted which means that Edison had infringed on this copyright. Porter and Edison's lawyers retorted that in order to copyright the whole film American Mutoscope and Biograph Company had to have copyrighted 8 photographs - one from each of the film's 8 shots - because the film is merely an agglomerate of 8 distinct and separate films. According to Gaudreault, whereas Biograph effectively argued that the film was narrated by combining shots into a unity, Edison claimed that no such narrating is taking place and that the film is simply a sequence of disparate shots. In the end, Judge Lanning sided with the former view stating:

I am unable to see why, if a series of pictures of a moving object taken by a pivoted camera may be copyrighted as a photograph, a series of pictures telling a single story like that of the complainant in this case, even though the camera be placed at different points, may also not be copyrighted as a photograph [...] In that story, it is true, there are different scenes. But no one has ever suggested that a story told in 
written words may not be copyrighted merely because, in unfolding its incidents, the reader is carried from one scene to another. (Quoted in Gaudreault 2009, 112).

To Gaudreault's mind '[t]his recognition of the film narrator [...] [establishes] the film equivalent of the textual narrator' (ibid., italics in the original). But as we can see from Gaudreault's ontological commitments and Genette's quote above the textual narrator is a fictional entity engaged in a fictional activity. When reading Tristram Shandy the readers are mandated to imagine that Tristram is writing the book which consists of exactly the same words as Sterne's book. Are we as viewers mandated to imagine anything similar in Personal or its dupe? A fictional agency in control of combining the shots and presenting them as a story? Nothing of the sort exists. I am not denying that there is a certain equivalence between different camera placements and carrying the reader from one scene to another, as Gaudreault puts it, but this equivalence is only on the level of narrating and not on the level of fictional narrating. Gaudreault's narratology, in other words, can only provide theoretical models for distinguishing the forms of narrative discourse but, unlike Genette's, it can tell us little about the fictional status of narrators.

What is important to note is that Gaudreault's recourse to historical data to support his theoretical point is not the problem here. It is reasonable to engage contemporary writing on the subject, because it is likeliest that as the cinema was becoming more narrative it is precisely at that moment that the textual features mandating the fictional narrator - if such a figure did appear - would have been spotted by contemporaries. The issue is that the contemporary judicial decision Genette cites merely demonstrates that the fictional story is narrated. Judge Lanning never suggests that the fictional story is fictionally narrated. 
The situation is similar with Gunning's study. Gunning distinguishes three aspects of narrative discourse - the pro-filmic, enframing, and editing. Whereas the profilmic concerns mise-en-scène in the theatrical sense of the word and enframing pertains to the manipulations of camera and film stock, editing is a matter of joining enframed shots together. In Gaudreault's vocabulary the first two aspects of narrative discourse are the monstrator's responsibility and the last one that of the narrator proper. Gunning, by contrast, prefers to speak of a single filmic narrator embodied by narrative discourse overall because the last aspect need not be necessarily present. ${ }^{\mathrm{v}}$ Gunning's point is that the filmic narrator becomes truly visible only with the developments taking place between 1908 and 1913 in what he dubs 'the narrator system' when moral commentary, characterization, and the formation of unambiguous temporal relations become more pronounced.

Gunning's analysis of Griffith's early films at Biograph is a detailed study of how each of the aspects of narrative discourse contributed to conveying moral commentary, characterization, and temporal relations in narrative fiction film. The book's problems arise, however, when the role of imagination is taken into consideration because these very films are at the same time understood to be narrated not only by Griffith the author but fictionally as well. For want of space I cannot consider all of Gunning's examples, so I will only tackle The Song of the Shirt (D.W. Griffith, 1908) in more detail which, as Gunning himself puts it, 'exemplifies Griffith's work in Genette's category of voice, expressing the filmic narrator's judgments about characters or actions through contrast edits' $(1994,132)$. 'For Genette,' Gunning continues, "voice refers to the act of narrating the story and to the elements of the text which refer to this act' (ibid.). And, to be perfectly clear, under Genette's model this act of narrating as well as its agent are necessarily fictional: 
[the] confusion [between the author and the narrator] is perhaps legitimate in the case of a historical narrative or a real autobiography, but not when we are dealing with a narrative of fiction, where the role of narrator is itself fictive. [...] it is this narrating instance that we have still to look at [under the category of voice], according to the traces it has left — the traces it is considered to have left—in the narrative discourse it is considered to have produced. (Genette 1980, 213-214)

The Song of the Shirt is a story of a seamstress who tries to find work in order to provide for her sick sister but once she does and completes the task she is refused payment. Her subsequent pleas with the factory owner and the foreman fall on barren ground and upon her return home her sister dies in front of her eyes.

Gunning identifies the final three shots as the core of the film's social commentary - whereas in the first shot the factory owner dances merrily with two girls and in the second the foreman wines and dines in the same upscale restaurant, in the last shot the seamstress' sister finally succumbs to her affliction in a shabby room. And Gunning also articulates the key role editing has in this process distinguishing between contrast editing whose primary concern is the juxtaposition of the lives of the wealthy and the poor, and parallel editing which is mainly motivated by temporal relations and deadlines. In other words, it is undeniable that the story is a social critique and that this critique has been articulated through narrative discourse. But this does not mean that anybody from the story world is responsible for this narrative discourse. As this typical entry from the catalogue attests, the story is simply shown without any fictional showing taking place: 'In this Biograph story are shown two orphaned sisters, in poverty and sickness, struggling to eke an existence, frugal though it be' (quoted in Niver 1971, 403). The viewers are not mandated to imagine anybody juxtaposing these shots in the way that the readers are mandated to imagine Tristram writing the story of his life. 
As far as the fictional narrator is concerned, nothing changes even when editing in Griffith becomes, to use Gunning's words, 'supernatural' or 'transcendental' as it does in After Many Years (1908). Shot eight in which the shipwrecked husband kisses the locket with the image of his wife inside is immediately followed by a shot of the wife with her hands outstretched as though she is trying to embrace her missing husband. Indisputably, we are no longer in the territory of using editing only for spatiotemporal relations, moral contrasts, or psychological characterization. But this does not warrant Gunning to claim that this cut ushers in a 'transcendent witness' involving 'a ménage à trois among husband, wife, and uniting narrator' (Gunning 1994, $113,114)$. Griffith is undeniably excelling in narrating as Sterne is, but unlike Sterne he is not involving any fictional narrators. Put otherwise, the cut is clearly a trace of narrating - but it is not a trace of fictional narrating. By identifying the company team rather than some fictional agency as the one responsible for the narrative, the catalogue entry also supports this view: 'The Biograph Company here presents a subject on the lines of Enoch Arden, although more intensely heart-stirring than the original story' (quoted in Niver 1971, 399).

If there is an early film which at least approaches what it would mean for there to be a fictional filmic narrator, then it is The Big Swallow (John Williamson, 1901). The film depicts a man angered by finding himself to be an object of a camera. To this he reacts by walking up to the recording device so close that only his mouth can be seen. At this point he swallows both the camera and the operator upon which he moves back to a close-up of his face in which he expresses his great satisfaction with the snack. But even in this film the audience is mandated to imagine somebody showing the film only to the point where the man's mouth covers the screen. In the remainder of the film there is no additional camera and no additional operator within the diegetic world 
standing at the very spot where the gobbled-up camera and operator stood and showing us the film's second part.

The catalogue entry for Williamson's film is also clear that the fictional showing is going on only halfway:

'I won't! I won't! I'll eat the camera first!' Gentleman reading, finds a camera fiend with his head under cloth, focusing him up. He orders him off, approaching nearer and nearer, gesticulating and ordering the photographer off, until his head fills the picture, and finally his mouth only occupies the screen. He opens it, and first the camera, and then the operator disappear inside. He retires munching him up and expressing his great satisfaction. ("Charles Urban Trading Co. November 1903 Catalogue", 115)

In contrast to the catalogue articulation of 'showing' discussed above, in The Big Swallow it is clear that the spectators are mandated to imagine 'a camera fiend' 'focusing [the gentlemen] up'. In other words, on those rare occasions when fictional showing in early cinema is mandated, it is likely to be recognized as such by contemporaries because, to repeat, mandates are a part of the text. Therefore, let us follow Gaudreault's lead and turn to the contemporary discourse which, given that it was directed at aspiring storytellers and practicing filmmakers at a time when these textually visible mandates would have been forming, arguably has the highest chance of identifying the fictional narrator in early cinema - screenwriting manuals and the discussions of narrative clarity in the trade press during the transitional era.

\section{Contemporary Narratological Discourse}

It is well known that narrative clarity was one of the key concerns in the transitional era when it comes to film's narrative function. Although in the US, as both Gunning and Gaudreault remind us, this demand for comprehensibility saw the renewed popularity of lecturers between 1908 and 1912, the ideal solution to meeting this demand was always 
with recourse to the visual track alone. The idea that the spectator should be able to reconstruct the story by simply looking at the screen appears at least as early as 1906 in an Edison Manufacturing Company's advertisement we read that their 'latest dramatic success [...] Kathleen Mavourneen [...] tells its own story - plainer than words' (New York Clipper, September 8, 1906, 766). By 1908 the issue of narrative comprehensibility arose to such prominence in the trade press that the following correspondence appeared:

\footnotetext{
Many a time I have watched a new film subject projected on the screen and thought to myself: If I only knew what this or that part of the picture meant, then I could get very much more enjoyment out of the entertainment. But how would it be possible for the theater manager to explain the film subjects unless the film manufacturer furnishes a printed description of each picture when they are sent out? I think that half of the time the theater manager himself does not understand the picture as it is projected on the canvas. If some film manufacturer would make every one of his film subjects explain themselves as they pass through the machine he would soon have all the business he could attend to. If instead of having a few words of explanation on his film about every 100 feet, as most of them do, they would have these explanations come in at every 20 or 30 feet (or at every place on film wherein an explanation was necessary), then the theater manager would have no use for a lecturer. [...] W. M. RHOADS. In reply: The idea of a lecturette is a good one, but one that few proprietors will take the trouble to arrange. For instance, Kalem Company arranged a lecturette or resume of the story of Evangeline to go with that film; we understand that so few exhibitors applied for it that the company abandoned the idea of reprinting. To issue titles every 100 feet would unnecessarily add to the cost of the film and is a little too much to ask renters to pay 12 cents per foot for title. We would blame the actors inasmuch as they did not render the story intelligently. A perfectly thought out plot, well put together, should tell its own story. (Moving Picture World, February 22, 1908, 143)
}

We are dealing with a crisis of narrative comprehensibility here and although various solutions are proposed in both the letter and the response to it - providing a synopsis to 
the audiences in the form of printed material, increasing the number of leaders, and using lecturers - the ideal solution that crystalizes is that the film 'should tell its own story'. This notion would remain the mainstay of thinking about the matter throughout the transitional era. ${ }^{\mathrm{vi}}$ As late as 1913, for instance, Adolph Zukor is reported as saying: 'We are trying to let the story tell itself so far as possible' (Pictures April 1913, 19). ${ }^{\text {vii }}$

To put it in Gunning's terms, the film learning to tell its own story amounts to developments in narrative discourse such as those he describes in his book on Griffith. So, for Gunning learning to tell its own story essentially translates to introducing the narrator who tells the story. My argument, however, is that these developments introduce no such mandates to imagine. Next to analytic arguments marshalled above and negative evidence of the absence of narrators in contemporary catalogues the positive proof for my claim can be found in the screenwriting manuals and instructions for screenwriters which start appearing with regularity around 1910. These documents strongly suggest that there is no fictional narrator in film and in doing so articulate an alternative to Gunning and Gaudreault's view.

Because film narrators, as I have argued above, are not only theoretical constructs but populate fictional worlds as well, contemporary accounts can tell us whether film narrators exist or not. Both the contemporary theorists and early manual writers make ontological claims about film narrators. As such contemporaries enter into dialogue with later accounts of film narrators starting with Laffay and Metz even if these do not mention the former. This is so because if something is fictional then there is a mandate to imagine it. Given that mandates are present for all to see (spectators and theorists alike), there is no reason to think that film narratologists since the 1960s have been in a more privileged position to spot these mandates than contemporaries. If anything, the novelty of these mandates would have been more noticeable to those 
witnessing the advent of narrative cinema, especially those invested in advising how to write film stories. What the following pages demonstrate is that the textual features that Gunning and Gaudreault take to be the sign of fictional film narrators, the contemporary screenwriters identify merely as sign of film as an artefact made by flesh and blood agents invested in narrating. Most likely this is because whereas Gunning and Gaudreault are subscribed to the idea that every (fictional) narrative has a (fictional) narrator, contemporaries understood that there are narratives which have no narrators. By the late aughts conditions in the American film industry led to such a demand for original fiction story films - or photoplays as they were called then - that the demand could not be met by the production companies' creative staff alone. To address this need, the producers turned to the open market and started soliciting scripts. This, in turn, opened a market for columns advising aspiring screenwriters, screenwriting textbooks, and even film magazines devoted exclusively to ‘photoplaywrigths'. For instance, as early as August 20, 1910 Film Index devoted a full page to William K. Mitchell's the 'Tribulations of a Scenario Writer'. William Lord Wright wrote columns 'For Those Who Worry O'er Plots and Plays' and 'For Photoplay Authors' for Motion Picture World (from March 1912) and New York Dramatic Mirror (from March 1913), respectively. Similarly, specialized magazines such as The Photo Playwright and Photoplay Author appeared in April 1912 and January 1913, respectively. By 1915 Clarence J. Caine could publish a book-length collection of his writings on the topic originally appearing in Picture-Play Weekly and Picture-Play Magazine. ${ }^{\text {viii }}$ The first textbooks such as E. J. Muddle's Picture Plays and How To Write Them and Ralph P. Stoddard's The Photo-play can be tracked to at least 1911 and, much like other commentary, readily promulgate the ideal of narrative clarity adopted from the preceding trade press commentary: 
The story must be told by a series of happenings. While titles and sub-titles are used, and often strengthen the interest in the story, no manufacturer would buy a Scenario which would not stand alone or carry its story to the audience by the pictures, regardless of the title. (Stoddard 1991, 9).

The idea that the story tells itself, or, as we read here that it is 'told by a series of happenings' strongly suggests the view that for contemporaries there is no unitary agent within this world of events that tells the story. Rather, based on the events that unfold in front of the spectator's eyes she can reconstruct the story. And the following analogy explains why this should come as no surprise. Consider a sports event of your own choosing. Regardless of the event you pick it turns out that you are dealing with a series of happenings which meets all the requirements of a minimal narrative in the same sense that a story on screen does. The sports event has a clearly defined beginning and an end, it unfolds chronologically, and a story can be reconstructed out of it with agents (players) having a role in non-causal events counting as disturbances in the equilibrium (playing the game). ${ }^{\mathrm{ix}}$ The story could go something like this: the reigning boxing champion is dominating through most of the fight but in the fifth round he is knocked out by a punch to the solar plexus. In fact, a boxing match was accounted for in narrative terms much like this in R. W. Paul's 1903 catalogue:

[The match] opens with the referee bringing the gloves into the ring $[\ldots]$ In the second round [Johnny] Hughes [the light weight-champion of England] is seen to get better of his opponent [Dido Plumb] [...] In the fifth and last round [...] [Plumb] hits him [Hughes] under his heart, which brings Hughes to the ground. $\mathrm{He}$ struggles hard to get up, but the blow has been too hard for him, and he is counted out, and the prize is awarded to Dido Plumb. $(1983,3)$

But is there anybody telling or, better yet, showing this story over and beyond the happenings on the sports arena themselves? Not the recording of the match, but the match itself? There might be a commentator near the ring, of course, but she cannot be 
the narrator in our sense of the term for she simply reports what she sees and is in principle in no more a privileged position to do so than we are. And even if the commentator was the narrator there are certainly sports events without commentators. There are happenings, therefore, which amount to narratives but have no narrators. Another example of such narratorless happenings which are nevertheless narratives are fictional happenings in plays. Just transfer the hypothetical boxing match on stage, have the actors make-believe they are boxing and the result is again a narratorless narrative but this time a fictional narratorless narrative. The spectators are mandated to imagine the same story as above and at the same time they are not mandated to imagine anybody showing the story. On a more general level, in plays there are again imaginary agents (characters) who interact in non-causal manner which brings them out of the initial equilibrium and supplies the content for imaginary story but provides no mandates for narrators of such stories. Importantly, the property of narratorial absence in plays was not lost to the contemporaries who advised on writing 'plays in photographs'.

Plays were seen to share much with the photoplays - certainly more than verbal narratives - because it was precisely the presentation of a story through visual action that was seen as common to both. Standard definitions of photoplay, for instance, put it like this: 'A photoplay is a play which is acted before the camera, and is shown to an audience by means of the moving picture' (Elbert Moore 1915, 18); 'the photoplay is nothing but a series of scenes in action which make up a story' (Berg J. Esenwein and Arthur Leeds 1913, 27); or 'it is a story told in pictured action instead of described in words' (Epes Winthrop Sargent 1913, 7). Verbal narratives, by contrast, were seen as having the luxury of long descriptions and slow development as opposed to the immediacy of visual action. In fact, the writers were often faulted for confusing written 
stories with photoplays. As a typical passage from the Photo Playwright attests: 'Most of the amateur scenario writers tell only a story - always write stories, and use long leaders, etc. A photoplay is an action-story. The action is the essential thing' (July 12, 1912, 15). Crucially, this distinction between verbal recounting and visual action translated into seeing plays and photoplays as sharing the absence of narratorial control. ${ }^{\mathrm{x}}$ As the manual by Howard T. Dimick explicitly states:

compulsory and self-explanatory causes and effects move the play without visible agency, save the cummulative [sic] circumstances which react upon the characters; in a [verbal] story the plot is frequently a matter of the author's will alone, and of his obtruding personality, which we feel to control the events $(1915,20)$.

Given that at the time 'author' as a term was used to denote both the author and the narrator - the separation would fully happen only with Genette's narratology - the underlying idea here is that verbal fiction in general mandates imagining somebody telling the story on top of somebody actually telling it. This is so because on most occasions in written fiction there is some attitude taken towards the events, some running commentary on the events and this commentary amounts to a part of the narrative discourse. Given that verbal fiction invites readers to imagine not only the content of narrative discourse (the story) but the narrative discourse itself (the narrating) and given that this narrative discourse reveals some characteristics of the speaker behind it ('obtruding personality'), Dimick finds it that readers are mandated to imagine a narrator which has those traits. Plays and photoplays, by contrast, although they are clearly artefacts as much as verbal fictions, do not mandate spectators to imagine any personality behind their narrative discourse - there is an asymmetry between them and written fiction. ${ }^{\mathrm{xi}}$ It is clear to Dimick that there is a team actually responsible for the narrative discourse - cameraman, director, actors, playwright, etc. - but by no means should anybody be imagined as behind the discourse: 
all the devices of the camera and its accessories are aimed at conveying through the medium of a sequence of pictures and pictured events a complete and selfexplanatory, dramatic action, which shall, by its appeal chiefly to the eye, unfold in the mind of the spectator satisfying effects and results of the playwright's labors. (ibid., 67)

There is undoubtedly a message and a sender responsible for it, but the content of the message does not mandate spectators to imagine a sender on top of the actual team behind the film.

What does distinguish plays from photoplays (next to the use of film recording technology and film specific devices, of course) is the absence of the screen actors' voices and recourse to written material such as titles, leaders and other types of inserts: 'A photoplay is a story told largely in pantomime by players, whose words are suggested by their actions, assisted by certain descriptive words thrown on the screen, and the whole produced by a moving-picture machine' (Esenwein and Leeds 1913, 1). Perhaps it is these verbal additions that might have revealed some fictional personality telling the story to the contemporaries after all?

Screenwriting manuals virtually never speak of lecturers attesting to their decline by 1912 so we are definitely not dealing with any lecturers as potential fictional narrators. It is the leaders and various other forms of written text that appear on screen that are the necessary evil in the pursuit of narrative clarity. Although the manuals make a recurrent point that 'the perfect motion picture has no subtitles and needs none' (Herbert Case Hoagland 1912, 14) they also readily admit that in practice there is no getting around them:

when this [the complete elimination of leaders] is attempted, the lucidity of the story is too liable to suffer, whereas an occasional leader of a few words will bridge over a certain combination of events, giving the story a clearness quickly grasped by the audience, and perhaps avoid the introduction of several minor 
scenes otherwise necessary to make the story intelligible. (William Lewis Gordon 1914, 17)

Esenwein and Leeds $(1913,180-185)$ are the most systematic among the manual authors when it comes to clarifying the four main functions of leaders: 1) highlighting the passage of time, 2) explaining on-screen action when the profilmic and filmic events do not provide sufficient representational clarity, 3) 'breaking' a scene to shorten the on-screen time of a given action, and 4) guiding the spectator's reception of the following scene.

Much like other authors Esenwein and Leeds also distinguish between leaders proper (e.g. 'After three years') and 'letters, clippings, and similar interests' (e.g. 'Darling John, I am forever yours - Mary'). In our vocabulary the distinction is one of non-diegetic as opposed to diegetic material. The former is somehow 'outside' the story-proper: 'the use of a leader is a frank confession that you [the photoplaywright] are incapable of "putting over" a point in the development of your plot solely by the action in the scenes-you must call in outside assistance, as it were' (ibid., 171). From the perspective of mandated imaginings, furthermore, whereas the former mandates only to imagine the content of the sentence - that three years have passed - the latter mandates not only to imagine that Mary is in love with John but that she also wrote the letter to John comprising these very words.

Contemporary authors of screenwriting manuals were fully aware of this because they clearly felt that the latter types of inserts, due to their specific narratological properties, presented less of an aesthetic problem than the former ones. As Esenwein and Leeds put it: 'no matter what other kind of insert you employ, it will doubtless seem to be more a part of the action than will a plain leader. For this reason it is best, whenever possible, to use a letter, telegram, news item, or some similar insert, in 
place of a leader' (ibid., 187). Caine, similarly, advises to 'try to make leaders word pictures, so that the cut-ins will be part of the scenes themselves' $(1915,196)$. In a description of a typical film, Sargent even explicitly states that the spectators are supposed to imagine the picture of the letter on screen as the visual appearance of the letter itself: 'in the library in the heroine's home $[\ldots][\mathrm{t}]$ he girl goes to the table and sits down to write. [...] a written letter blots out the library. It is just as though we read the letter over her shoulder' $(1913,14)$. Esenwein and Leeds add that there is a 'ridiculous practice of many studios in having all their letters in films written in the same handwriting. A note written by a schoolboy, another penned by a society woman, and a letter laboriously spelled out by a tramp, all appear, to judge by the handwriting, to have been written by the same person' $(1913,190)$. The suggestion is that the letters written by different people should be graphically distinguishable because spectators are mandated to imagine that the graphemes in question not only represents the content of the letter but also the visual appearance of the letter.

Why does all this matter for the discussion of narrators? Because although contemporaries recognized the distinction between written inserts that are a part of the imaginary world (letters, clippings, etc.) and those which only describe that imaginary world being only a part of the film's visual track (leaders proper), neither were seen as mandating any imaginings about the narrator:

Few in an audience will object to the introduction of letters, telegrams, newspaper items, and the like — provided there are not too many such inserts—-because these seem to fit into the picture as a part of the action, and are not, like leaders, plainly artificial interpolations by the author. (ibid.)

The artificial-looking leaders are not sign of some imaginary narrator but simply marks of the director's and the photoplaywright's failure to convey the story through action (and occasional letter, clipping, etc.) alone. Even though, as I mentioned earlier, the 
term 'author' denoted both the author and the narrator at the time, Esenwein and Leeds are not talking about the author as the fictional narrator here for, unlike Dimick, there is no reference to anything like 'obtruding personality'. Dimick's point is that in verbal fiction it is often but not always the case that there is some running commentary which is indicative of personal traits of the narrator to be imagined. A good example of this is again Tristram Shandy. But on other occasions like Arthur Schnitzler's The Dream Story where the information is conveyed in a matter-of-fact style no such personality comes forth. In these cases, Dimick denies the presence of an obtruding personality - a distinguishable narrator - but in saying so clearly does not suggest that this means that the stories in question have no authors. In other words, the difference between the author and the narrator is sufficiently clear. The 'artificial interpolations by the author' are interpolations of the actual agent of narrative discourse.

It is true that the notion of 'obtruding personality' is not identical to what Genette has in mind when he speaks of narrators. For him every narrative, regardless of whether it is told by an imaginary character with a name such as Tristram Shandy or anonymously 'in third person', has a fictional narrator. So 'obtruding personality' is a subset of extradiegetic narrators. But 'obtruding personality' is what Gunning takes Griffith's moral and other commentary to be. And yet, as we have seen, contemporary trade press denies this view.

'Obtruding personality', moreover, is not the most fortunate way to approach the figure of the narrator in fiction film not least of all because the camera and the operator in The Big Swallow are not identifiable to the spectator during the first half of the film at all - their presence is revealed only retroactively and after they have been robbed of the narratorial role. This is not to deny, however, that for the contemporaries the notion of 'obtruding personality' did important work. It contributed to a greater understanding of 
literary and film fiction insofar it distinguished the two from the perspective of narratorial control and implicit mandates behind this control. In other words, contrary to present-day scholars they were more apt in recognizing that unlike standard literary narratives, film narratives have no fictional narrators.

In the final instance, it might be objected that if 'obtruding personality' is only a subset of extradiegetic narrators there is space for impersonal narrators even in film. After all, Genette has claimed that even literary 'third person' narratives have fictional narrators and Metz (1991) has explicitly argued for impersonal enunciation in film. The problem with Metz's idea is that although there is good reason to imagine impersonal literary narrators based on linguistic deictic markers (e.g. 'I', 'yesterday', 'here', etc.), there are no analogues to deictic markers in film (Slugan 2015). And even if accepted Metz's claim about a singular but general deictic accompanying every shot in film 'there is' - we have no reason to think that the deictic is fictional. In Genette's terms, whereas the deictics in literary fiction do not refer to the act of actual writing but to the act of fictional narrating, the filmic 'there is' refers to the actual act of producing the film image. Put differently, films can tell their own fictional stories without any fictional narrators - a fact which contemporary screenwriting manuals recognized but which has eluded later theorists and historians.

\section{References}

Azlant, Edward. 1980. The Theory, History, and Practice of Screenwriting, 1897-1920. Madison: University of Wisconsin-Madison.

Azlant, Edward. 1997. "Screenwriting for the Early Silent Film: Forgotten Pioneers, 1897-1911." Film History 9(3): 228-256.

Black, David Alan. 1986. "Genette and Film: Narrative Level in the Fiction Cinema." Wide Angle 8 (3/4): 19-26. 
Braudy, Leo, and Marshall Cohen (eds). 1999. Film Theory and Criticism: Introductory Readings. 5th Ed. Oxford University Press.

Caine, Clarence J. 1915. How to Write Photoplays. Philadelphia: D. McKay.

Casetti, Francesco. 1998. Inside the Gaze: The Fiction Film and its Spectator. Bloomington: Indiana University Press.

“Charles Urban Trading Co. November 1903 Catalogue.” 1983. In Early Filmmakers' Catalogues. London: British Film Institute.

Chatman, Seymour. 1990. Coming to Terms: The rhetoric of Narrative in Fiction and Film. Ithaca, NY: Cornell University Press.

Curran, Angela. 2016. "Fictional Indeterminacy, Imagined Seeing, and Cinematic Narration." In Current Controversies in Philosophy of Film, edited by Katherine Thomson-Jones, 99-114. Routledge.

Esenwein, Berg J. and Arthur Leeds. 1913. Writing the Photoplay. Springfield, MA: The Home Correspondence School.

Dimick, Howard T. 1915. Photoplay Making; A Handbook Devoted to the Application of Dramatic Principles to the Writing of Plays for Picture Production. Ridgewood, N.J.: The Editor Co.

Gaudreault, André. 2009. From Plato to Lumière: Narration and Monstration in Literature and Cinema. Toronto: Toronto University Press.

Gaudreault, André, and François Jost. 1999. "Enunciation and Narration.” In A Companion to Film Theory, edited by Toby Miller and Robert Stam, 45-64. Oxford: Blackwell.

Genette, Gérard. 1980. Narrative Discourse: An Essay in Method. Translated by Jane E. Lewin. Ithaca, NY: Cornell University Press.

Gordon, William Lewis. 1914. How to Write Moving Picture Plays. Cincinnati: Atlas Pub. Co.

Gunning, Tom. 1994. D. W. Griffith and the Origins of American Narrative Film. Urbana: University of Illinois Press.

Hoagland, Herbert Case. 1912. How to Write a Photoplay. New York: Magazine maker publishing company.

Keil, Charlie. 2001. Early American Cinema in Transition: Story, Style, and Filmmaking, 1907-1913. Madison: University of Wisconsin Press.

Kozloff, Sarah. 1988. Invisible Storytellers. Berkeley: University of California Press. 
Niver, Kemp R. 1971. Biograph Bulletins, 1896-1908. Los Angeles: Locare Research Group.

Metz, Christian. 1974. Film Language; A Semiotics of the Cinema. New York: Oxford University Press.

Metz, Christian. 1991. "The Impersonal Enunciation, or the Site of Film (in the Margin of Recent Works on Enunciation in Cinema)." New Literary History 22(3): 747772.

Moore, Elbert. 1915. Elbert Moore's Text Book on Writing the Photoplay. Chicago: E. Moore.

Muddle, E. J. 1911. Picture Plays and How to Write Them. London: The Picture Play Agency.

“R. W. Paul Film 1903 Catalogue.” 1983. In Early Filmmakers' Catalogues. London: British Film Institute.

Ryan, Marie-Laure. 2007. "Toward a Definition of Narrative." In The Cambridge Companion to Narrative, David Herman, 22-35. Cambridge: Cambridge University Press.

Sargent, Epes Winthrop. 1913. The Technique of the Photoplay. New York: The Moving Picture World.

Slugan, Mario. 2015. "Deixis in Literary and Film Fiction: Intra-Ontological Reference and the Case of the Controlling Fictional Narrator," In How to Make Believe: The Fictional Truths of Representational Arts, edited by Alexander J. Bareis and Lene Nordrum, 185-202. New York; Berlin: De Gruyter Press.

Slugan, Mario. 2019. Noël Carroll and Film: A Philosophy of Art and Popular Culture. Bloomsbury: London.

Slugan, Mario. 2019. Fiction and Imagination in Early Cinema: A Philosophical Approach to Film History. Bloomsbury: London. [forthcoming]

Stoddard, Ralph P. 1911. The Photo-play, a Book of Valuable Information for those Who Would Enter a Field of Unlimited Endeavor. Cleveland.

Verstraten, Peter. 2009. Film Narratology. Toronto; Buffalo: University of Toronto Press.

Walton, Kendall. 1990. Mimesis as Make-Believe: On the Foundations of the Representational Arts. Cambridge, MA: Harvard University Press.

Wilson, George: 2011. Seeing Fictions in Film: The Epistemology of Movies. Oxford: Oxford University Press. 
${ }^{i}$ Next to Christian Metz some notable authors include Sarah Kozloff (1988), François Jost (1999), David A. Black (1986), Seymour Chatman (1990), Francesco Casetti (1998), Peter Verstraten (2009), and George Wilson (2011). The most prominent exception is David Bordwell (1985). Although there is little debate on this matter among film scholars in general, it is very lively among those applying analytic philosophy to film. For recent contributions see Angela Curran (2016) and Mario Slugan (2015, 2019).

ii Gunning's view has at least since 1999 even been included in perhaps the most widely read reader on film studies - Leo Braudy's and Marshall Cohen's Film Theory and Criticism: Introductory Readings. This attests to the fact that this view of film narrators is formative.

iii It is important to remember that for Genette 'extradiegetic' does not mean outside the story world but on the lowest narrative level. Both Tristram Shandy and the anonymous narrator of Pere Goriot are extradiegetic for Genette.

${ }^{\text {iv }}$ For a detailed account of fiction as mandated imagining see Kendall Walton (1990). For a book-length application of Walton's theory to early cinema see Mario Slugan (2019).

v This approach also has an added benefit on minimizing the number of theoretical entities - in Gaudreault there is a proliferation of film narrators which include pro-filmic monstrator, filmographic monstrator, filmographic mega-monstrator, filmographic narrator, and film mega-narrator (the great image maker).

${ }^{\text {vi }}$ For a detailed account of demands for narrative clarity in the transitional era see Charlie Keil (2001). Importantly, the historical part of my argument about the inexistence of film narrators does not hinge on whether the crisis of narrative comprehensibility was as acute as I suggest or whether the strategy of films telling their own stories was indeed the ideal one and accepted by all. Rather, it hinges on what screenwriters meant when describing films as telling their own stories and on their accounts of leaders.

vii I would like to thank one of the anonymous reviewers for this reference.

viii For an in-depth history of American screenwriting see Edward Azlant (1980, 1997).

${ }^{\text {ix }}$ Cf. Marie-Laure Ryan's (2007).

${ }^{x}$ This distinction mirrors the classic Aristotelian mimesis/diegesis distinction with mimesis understood as direct imitation and diegesis as narrative representation.

${ }^{x i}$ Gaudreault insists that there is an agent responsible for showing the happenings on stage - the monstrator. Although generally invisible the traces of his activity, according to Gaudreault, can be seen in the use of techniques such as prologue and epilogue as well as devices characteristic of epic and expressionist theater (placards, voice-off, gestus, etc.). 
We are again dealing with a formally invalid argument which claims that the presence of a narrative discourse conveying a fictional story necessary entails the existence of a fictional narrator. Cf. Gaudreault (2009, 72-80). 